\title{
Influence of Atmospheric Clearness on PDLC Switchable Glazing Transmission
}

Aritra Ghosh

Technological University Dublin, a.ghosh@exeter.ac.uk

Brian Norton

Technological University Dublin, brian.norton@tudublin.ie

Tapas K. Mallick

University of Exeter, Penryn, Cornwall, UK

Follow this and additional works at: https://arrow.tudublin.ie/engschcivart

Part of the Materials Science and Engineering Commons, and the Other Engineering Commons

\section{Recommended Citation}

Ghosh, A. Norton, B. \& Mallick, T.K. (2018) Influence of atmo- spheric clearness on PDLC switchable glazing transmission, Energy \& Buildings, doi: 10.1016/j.enbuild.2018.05.008

This Article is brought to you for free and open access by the School of Civil and Structural Engineering at ARROW@TU Dublin. It has been accepted for inclusion in Articles by an authorized administrator of ARROW@TU Dublin. For more information, please contact arrow.admin@tudublin.ie, aisling.coyne@tudublin.ie, gerard.connolly@tudublin.ie.

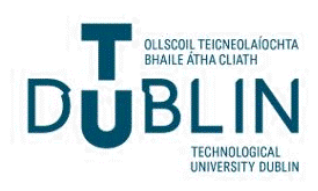




\section{Accepted Manuscript}

Influence of atmospheric clearness on PDLC switchable glazing transmission

Aritra Ghosh, Brian Norton, Tapas K. Mallick

PII:

S0378-7788(18)30075-6

DOI:

10.1016/j.enbuild.2018.05.008

Reference:

ENB 8549

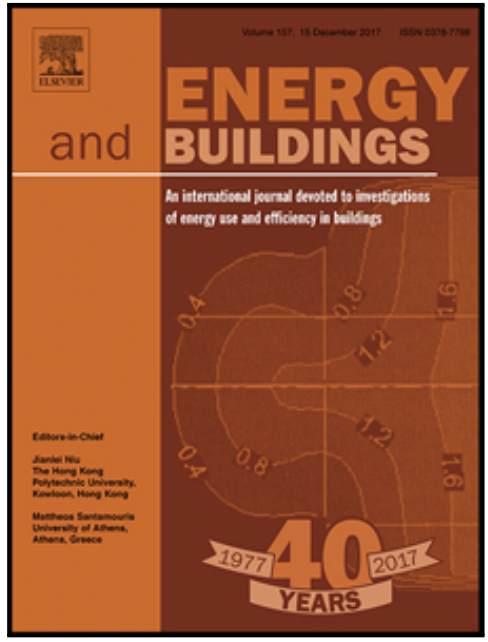

To appear in:

Energy \& Buildings

Received date:

8 January 2018

Revised date:

21 March 2018

Accepted date:

5 May 2018

Please cite this article as: Aritra Ghosh, Brian Norton, Tapas K. Mallick, Influence of atmospheric clearness on PDLC switchable glazing transmission, Energy \& Buildings (2018), doi: 10.1016/j.enbuild.2018.05.008

This is a PDF file of an unedited manuscript that has been accepted for publication. As a service to our customers we are providing this early version of the manuscript. The manuscript will undergo copyediting, typesetting, and review of the resulting proof before it is published in its final form. Please note that during the production process errors may be discovered which could affect the content, and all legal disclaimers that apply to the journal pertain. 


\section{Highlights:}

- Correlation between PDLC glazing transmittance and sky clearness index has been calculated.

- Transmitted solar energy and SHGC were evaluated for different clearness index.

- Single glazing transmittance was recommended for different azimuthal orientation of vertical plane PDLC glazing.

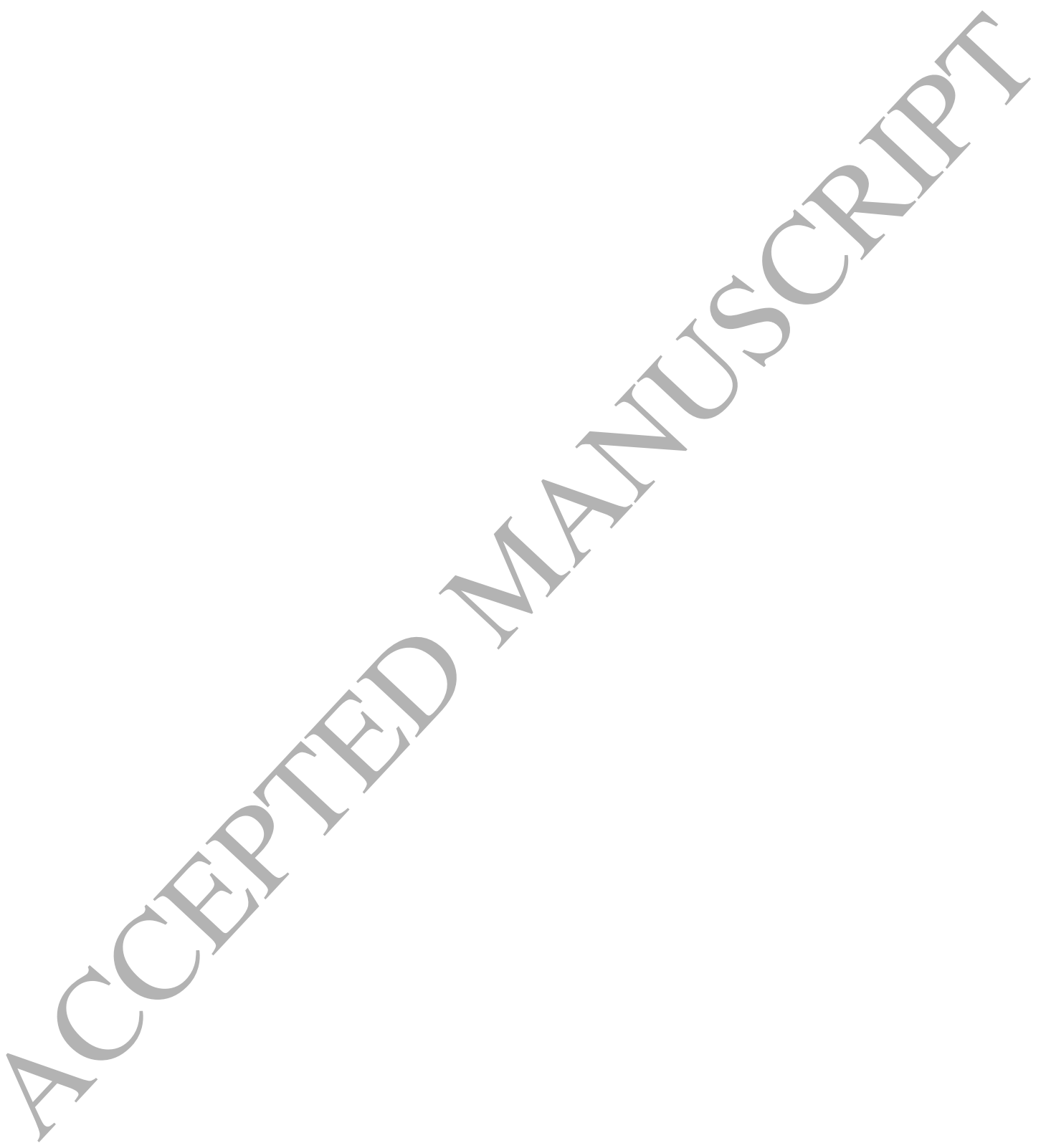




\title{
Influence of atmospheric clearness on PDLC switchable glazing transmission
}

\author{
Aritra Ghosh ${ }^{* 1,2}$, Brian Norton ${ }^{2}$, Tapas K. Mallick ${ }^{1}$ \\ ${ }^{1}$ Environmental and Sustainability Institute, University of Exeter, Penryn, Cornwall, UK \\ ${ }^{2}$ Dublin Energy Lab, Dublin Institute of Technology, Dublin, Ireland
}

*Corresponding author:

Email: a.ghosh@exeter.ac.uk

\section{Nomenclature}

$\mathrm{A}_{\mathrm{i}}$

$\mathrm{I}_{\text {global,h }}$

$I_{\text {global,v }}$

$\mathrm{I}_{\text {beam,h }}$

$\mathrm{I}_{\mathrm{dif}, \mathrm{h}}$

$\mathrm{I}_{\text {extra }}$

$\mathrm{I}_{\mathrm{sc}}$

$\mathrm{k}_{\mathrm{d}}$

$\mathrm{k}_{\mathrm{g}}$

$\mathrm{k}_{\mathrm{T}}$

$\mathrm{N}_{\mathrm{g}}$

$\mathrm{n}$

SHGC

$\mathrm{TSE}_{\text {PDLC }}$

Greek symbols

$\alpha$

$\tau$

$\tau_{\mathrm{v}}$

$\tau_{\text {dir }}$

$\tau_{\text {diff }}$

$\tau_{\mathrm{g}}$

$\theta$
Anisotropy index

Incident global solar radiation on the horizontal surface of glazing $\left(\mathrm{W} / \mathrm{m}^{2}\right)$

Incident global solar radiation on the vertical surface of glazing $\left(\mathrm{W} / \mathrm{m}^{2}\right)$

Incident beam solar radiation on the horizontal surface $\left(\mathrm{W} / \mathrm{m}^{2}\right)$ Incident diffuse solar radiation on the horizontal surface $\left(\mathrm{W} / \mathrm{m}^{2}\right)$ Extra-terrestrial solar radiation $\left(\mathrm{W} / \mathrm{m}^{2}\right)$

Solar constant $\left(\mathrm{W} / \mathrm{m}^{2}\right)$

Diffuse fraction

Extinction coefficient

Clearness index

Number of glass pane

Refractive index

Solar heat gain coefficient

Transmitted solar energy through PDLC glazing

Absorptance

Transmittance

Vertical global transmittance

Direct transmittance

Diffuse transmittance

Ground reflected transmittance

Incidence angle

\begin{abstract}
:
Electrically activated switchable polymer dispersed liquid crystal (PDLC) is suitable for adaptive windows. A particular type requires $20 \mathrm{~V}$ to become $71 \%$ transparent while in the absence of power it is $27 \%$ transparent. Glazing transmission changes with light incident angle. As the clearness of a sky changes the fraction changes alter of direct insolation (that has an azimuthally changing incident) and diffuse insolation (that has a largely constant incident). Thus, the effective overall incident angle determining the glazing transmittance also changes. In this work for the first time, the variation of
\end{abstract}


PDLC glazing transmission with clearness index has been investigated. For diffuse sky condition, single glazing transmittance value can be used below a particular clearness index for building energy calculation. This threshold clearness index changes with different azimuthal direction. In Dublin for south facing vertical plane PDLC glazing, yearly usable single transmittance (38\% for transparent and $25 \%$ for translucent state), transmitted solar energy (TSE) $\left(70 \mathrm{~W} / \mathrm{m}^{2}\right.$ for transparent state and $20 \mathrm{~W} / \mathrm{m}^{2}$ for translucent state) and solar heat gain coefficient (SHGC) (0.17 for transparent state and 0.005 for translucent state) for transparent and translucent states were investigated.

Keywords: adaptive, switchable glazing, PDLC, SHGC, transmission, clearness index

\section{Introduction}

Large glazed façade building elements [1,2] enable commercial and residential buildings to exploit heating energy and daylight [3] from sun [4,5]. Electrically actuated switchable material filled double glazings in such large façade applications offer better control when compared with non-electrically activated switchable glazing. In additions, electrically actuated switchable glazings

- offer more than one transmittance and intermittence transmittance by applying variable power [6-9];

- can control glare[7-10];

- provide daylight where spectrum has a positive influence on occupant comfort[8-10];

- can be powered by connected with PV [11-15];

- addition with vacuum glazing [16-18] electrically activated glazing can form a low heat loss switchable glazing [19-25];

Electrically actuated glazings include electrochromic (EC) [26], suspended particle device (SPD) [27] and polymer dispersed liquid crystal (PDLC)[6] type. Electrically activated EC glazing is powered by direct current power supply. Tungsten trioxide $\left(\mathrm{WO}_{3}\right)$ based EC is the well-studied for glazing system [28] in which an ion-conducting polymer or inorganic material based transparent electrolyte is sandwiched between nanoporous $\mathrm{W}$ and Ni oxide films. These three layers are placed between two transparent electrical conductors. The functioning of an EC devices is very similar to an electrical battery[29-31]. A voltage applied between these two transparent conductors changes the color of EC material to absorb solar spectrum. In the absence of power, the EC is transparent (bleached). An EC material can control near infrared solar radiation. Modulation of NIR is also possible of EC glazing $[26,32]$. Colour changes of EC is gradual depending proportionally on the area of the device. An EC changes colour between 1 and $30 \mathrm{~min}$, depends on the device area [33].

An SPD glazing consist of an SPD film, sandwiched between two glass panes, adhesive films, retaining films and a transparent conductor [34] . An SPD film is made of needle-shaped, rod-shaped, or lath-shaped dihydrocinchonidine bisulfite polyiodide or herapathite particles less than $1 \mu \mathrm{m}$ in linear size $[35,36]$. These particles exhibit large optical anisotropy. In the presence of alternating current power supply, these particles become aligned to pass light through the film. In the absence of power, the particles exhibit Brownian movement. Thus, the light passing through the cell can be transmitted, absorbed or rejected, depending upon type and concentration of particles and the energy content of the light. The optical change of SPD glazing from transparent to opaque and from opaque to transparent both needs only few seconds $[20,37,38]$. However, particular example of this glazing needs high $110 \mathrm{~V}$ AC to become transparent. Long term durability of this technology is also not fully understood [38]. 
Alternative current (AC) powered electrically activated switchable liquid crystal (LC) is another switchable glazing technology [39]. Polymer dispersed liquid crystals (PDLC) are the best suited for glazing application as they do not need a polarizer to operate compared to twisted nematic, ferroelectric [40,41]. In a PDLC glazing, liquid crystal particles are dispersed into a matrix. The presence of a power supply, orients the particles to allow light pass through. In the absence of power, these particles are randomly oriented so lights is scattered. Droplets with radii smaller than the incident light wavelength allow light to pass through without scattering. For large size droplets mainly forward scattering ensues [42]. Reverse mode PDLC have also been investigated in which the glazing is unpowered when transparent and powered to be opaque[43,44]. Figure 1 shows the working principle of PDLC glazing.

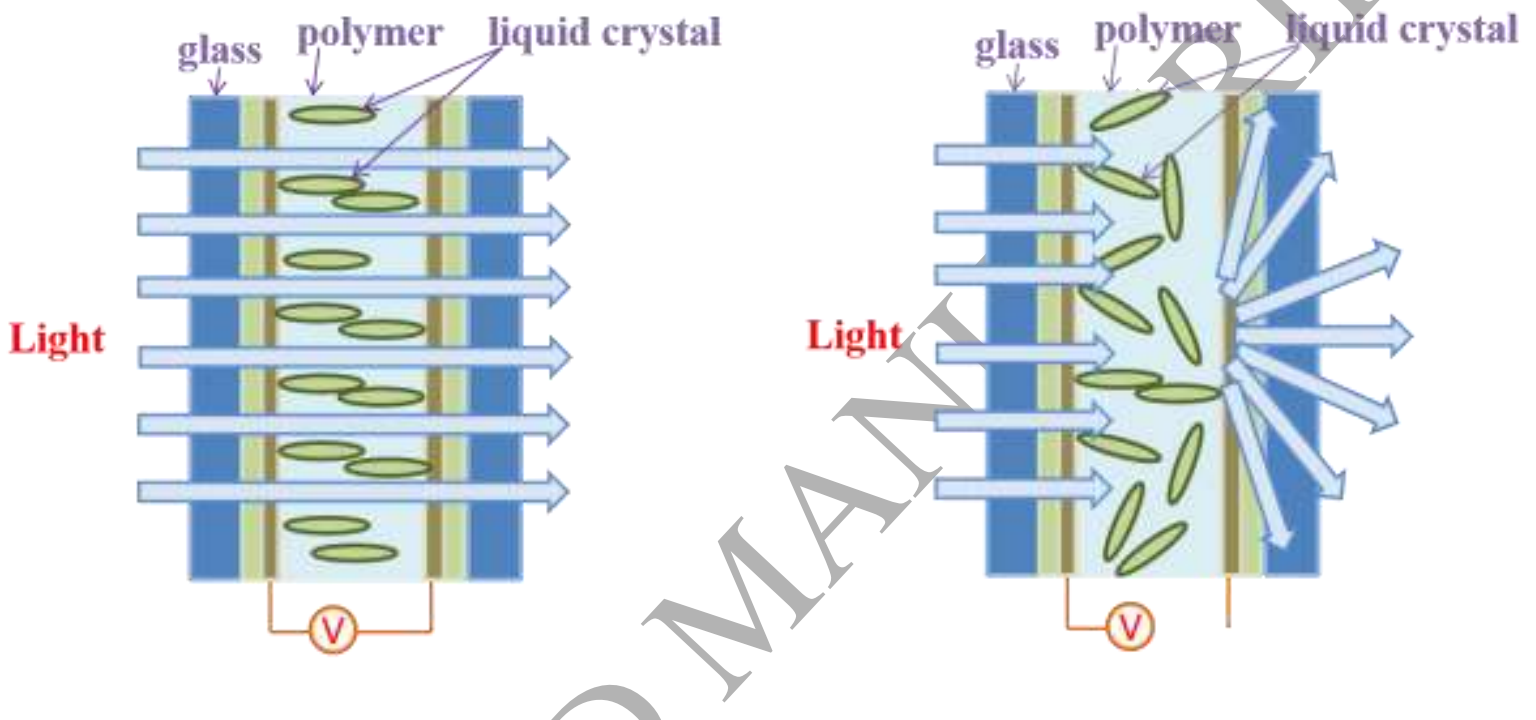

Figure 1: Schematic working principle of PDLC glazing in its transparent and translucent states.

Transmitted incident solar radiation through a glazing system depends on the optical properties of the glazing and incident-angles of the direct, diffuse and ground reflected solar radiation components. Incident angle for a vertical glazing façade also changes with time of a day and season [45-49]. Thus, calculated solar energy for a building based on constant glazing transmittance often leads to an overestimated result. For building energy calculations, incident solar radiation and glazing transmittance are essential parameters. Horizontal global and horizontal diffuse solar radiation data are often available for a particular location. However, glazings are usually installed vertically to receive vertical solar radiation. Clearness index uses global horizontal solar radiation to determine how "clear" a sky is [50-52]. Theoretically, the relation between glazing transmission and clearness index was investigated for selected European locations and surface orientations by Waide and Norton [53]. Experimentally correlations between SPD glazing [54], vacuum glazing [17] and SPD-vacuum glazing [19] with clearness index had also been investigated.

In this work, the first correlation between clearness index and measured PDLC glazing transmittance has been evaluated.

\section{Methodology}

A schematic of south facing vertical plane PDLC glazing is shown in Figure 2. 


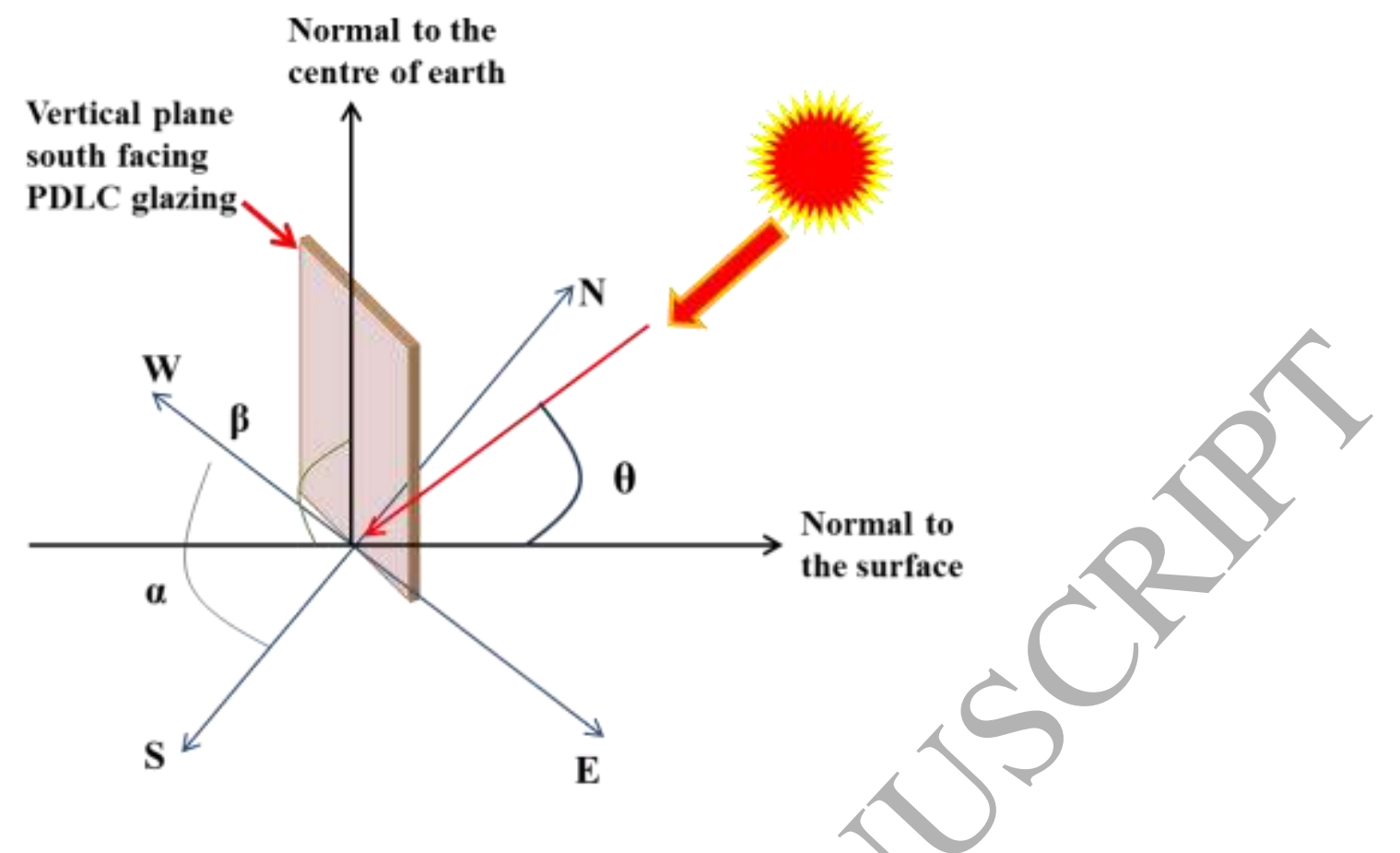

Figure 2: Schematic diagram of a south facing vertical plane glazing with incident angle and solar elevation angle.

The clearness index is given by

$$
\begin{aligned}
& k_{T}=\frac{I_{\text {global }, h}}{I_{\text {extra }}} \\
& I_{\text {extra }}=I_{s c}\left(1+0.033 \cos \frac{360 n_{1}}{365}\right)(\cos \phi \cos \delta \cos \omega+\sin \phi \sin \delta)
\end{aligned}
$$

$I_{s c}$ is the solar constant, $\mathrm{h}_{1}$ is the day of year, $\phi$ latitude angle, $\delta$ declination angle $\omega$ hour angle

Most often glazing transmittance value associated with only normal solar incidence. Glazing transmission is not a constant parameter; it changes with incident angle [47-49]. Incident angles also change due to diurnal variation of solar radiation. The transmittance of the vertical glazing is given by [53]

$$
\begin{aligned}
& \tau_{v}=\left[k_{d}^{\prime}\left\{k_{T} R_{b}\left(1-k_{d}\right)+(1-\cos \beta)\left(1-k_{T}\left(1-k_{d}\right)\right)\right\}+R_{b}\left(1-k_{d}\right)+R_{g} \frac{1-\cos \beta}{2}\right] \times \\
& \tau_{d i r} R_{b}\left(1-k_{d}\right)\left(1+k_{d} k_{T}\right)+\frac{\tau_{d i f} k_{d}}{2}(1+\cos \beta)\left(1-k_{T}\left(1-k_{d}\right)\right)+\frac{\tau_{g} R_{g}(1-\cos \beta)}{2}
\end{aligned}
$$

where 
$\tau=\frac{1}{2}\left[\frac{1-\left\{\frac{\sin (\theta-n)}{\sin (\theta+n)}\right\}^{2}}{1+\left(2 n_{g}-1\right)\left\{\frac{\sin (\theta-n)}{\sin (\theta+n)}\right\}}+\frac{1-\left\{\frac{\tan (\theta-n)}{\tan (\theta+n)}\right\}^{2}}{1+\left(2 n_{g}-1\right)\left[\frac{\tan (\theta-n)}{\tan (\theta+n)}\right]^{2}}\right] \times \exp \left(\frac{-k_{g} N_{g} t_{g}}{\cos \theta}\right)$

and direct diffuse and reflected transmission can be calculated from [55]

$\tau=\tau_{d i r}$ when $\theta=\theta_{d i r}$

$\tau=\tau_{\text {dif }}$ when $\theta=\theta_{\text {dif }}=59.68-0.1388 \beta+0.001497 \beta^{2}$

$\tau=\tau_{g}$ when $\theta=\theta_{g}=90-0.5788 \beta+0.002693 \beta^{2}$

The total solar energy transmitted through a PDLC glazing is given by;

$$
\begin{gathered}
T S E_{P D L C, \text { glazing }}=\left(I_{\text {beam }, h}+I_{d i f, h} A_{i}\right) \tau_{d i r} r_{b}+I_{d i f, h}\left(1+A_{i}\right) \tau_{d i f, h} \frac{(1+\cos \beta)}{2}+ \\
I_{\text {global }, h} \rho_{g} \tau_{g} \frac{(1-\cos \beta)}{2}
\end{gathered}
$$

anisotropy index $\left(\mathrm{A}_{\mathrm{i}}\right)$ is given by

$$
A_{i}=\frac{I_{\text {beam }, h}}{I_{\text {extra }}}
$$

Solar heat gain coefficient (SHGC) for a glazing indicates the fraction of the incident solar radiation that enters a room after passing through the glazing [56][57]. The dynamic solar heat gain coefficients (SHGC) is calculated from

$$
S H G C=\frac{T S E_{P D L C}}{I_{\text {global }, v}}
$$

\section{Measurements \& results}

In this work, one PDLC glazing from Polytron technology as shown in Figure 3 was investigated. This glazing had dimension of $0.2 \mathrm{~m} \times 0.15 \mathrm{~m} \times 0.01 \mathrm{~m}$. It became $71 \%$ transparent in the presence of a $20 \mathrm{~V}$ AC power supply and $27 \%$ transparent without a power supply [6]. In the powered state, it had a low diffuse transmittance (7\%) and high regular/specular transmittance $(64 \%)$. In the switch off state it has high diffuse transmittance of $26 \%$ and low specular transmittance of $1 \%$ [57]. The unpowered state showed $83 \%$ haze. Spectral transmittance of this glazing was measured using 
AvaSpec-ULS2048L Star Line Versatile Fiber-optic spectrometer for both states results are shown in Figure 4.

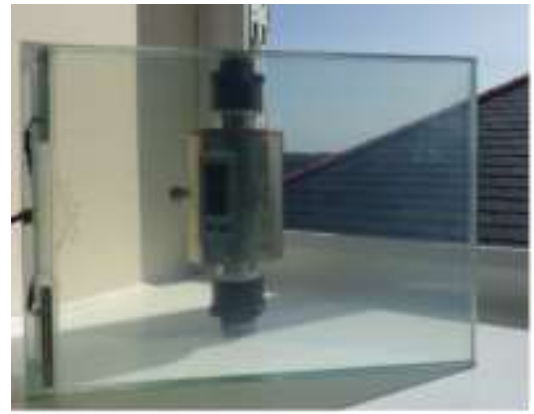

PDLC switch on / transparent $(71 \%)$

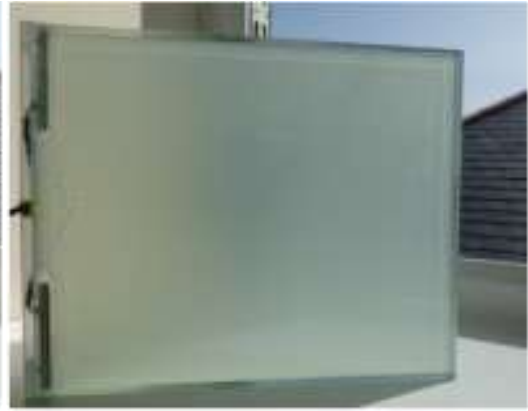

PDLC switch off / translucent $(27 \%)$

Figure 3: Viewing through the investigated PDLC glazing for it transparent and translucent states.

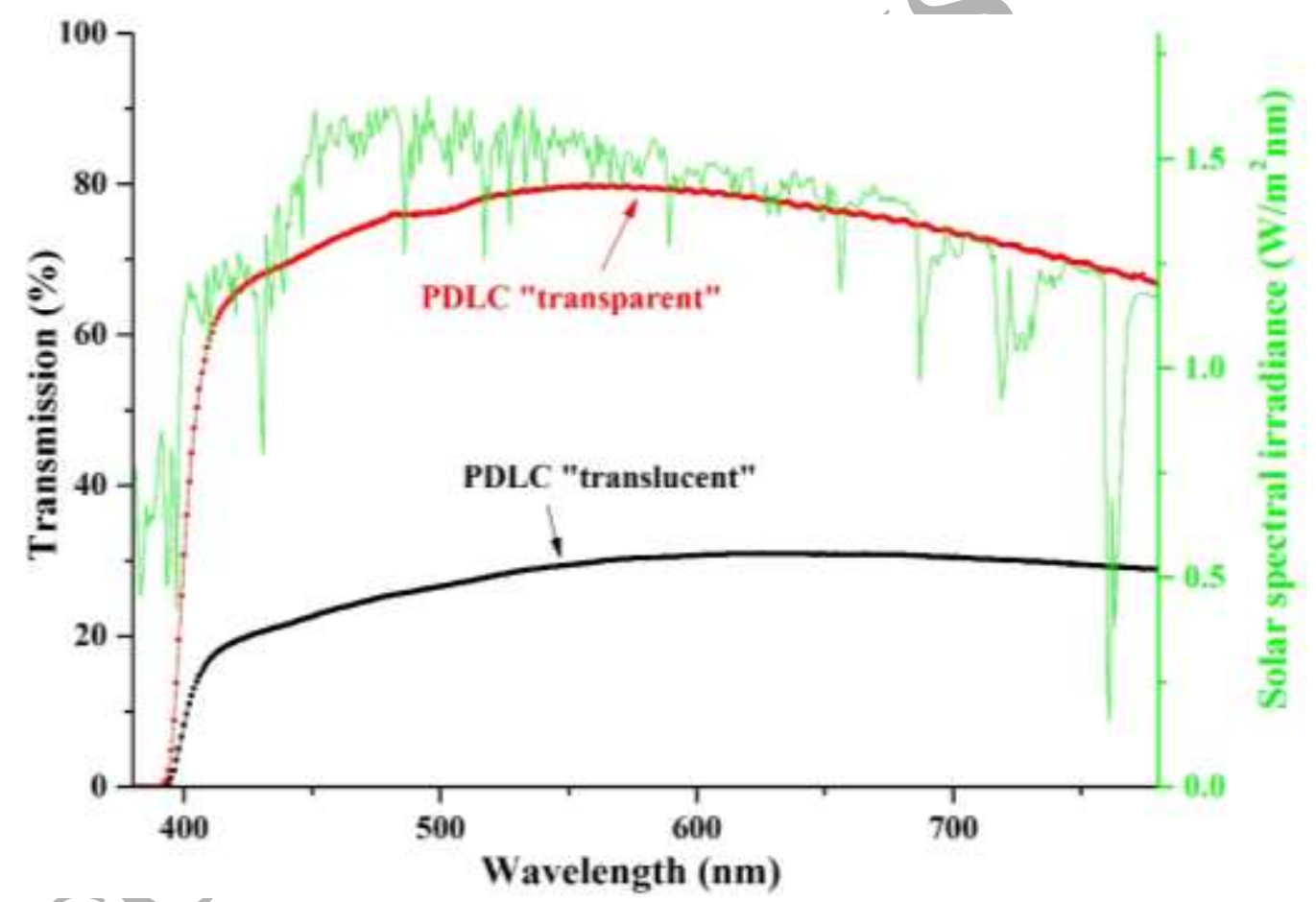

Figure 4: Transmission spectra of the particular PDLC glazing investigated in its "translucent" and "transparent" states.

A $0.7 \times 0.7 \mathrm{~m} \times 0.7 \mathrm{~m}$ test cell as shown in Figure 5 was manufactured from wood lined inside with a $0.15 \mathrm{~m}$ thick polystyrene insulation material with unobstructed solar illuminance. Internal surfaces were painted with 0.8 reflectance matt white paint. The area of glazing on the test cell was in a ratio of 1:9. Horizontal plane global solar radiation, horizontal plane diffuse solar radiation, vertical plane global solar radiation was measured using Kipp and Zonen pyranometers [13-14,20-23,38,]. AvaSpecULS2048L Star Line Versatile Fiber-optic spectrometer measured transmission of this glazing. 5 minutes interval data were recorded using delta $\mathrm{T}$ type data logger. Experiment was performed from 
$1^{\text {st }}$ of January to $1^{\text {st }}$ of December 2016, on the roof of Kevin street building, at Dublin Institute of Technology, Dublin $\left(53.3478^{\circ} \mathrm{N}, 6.2597^{\circ} \mathrm{W}\right)$.

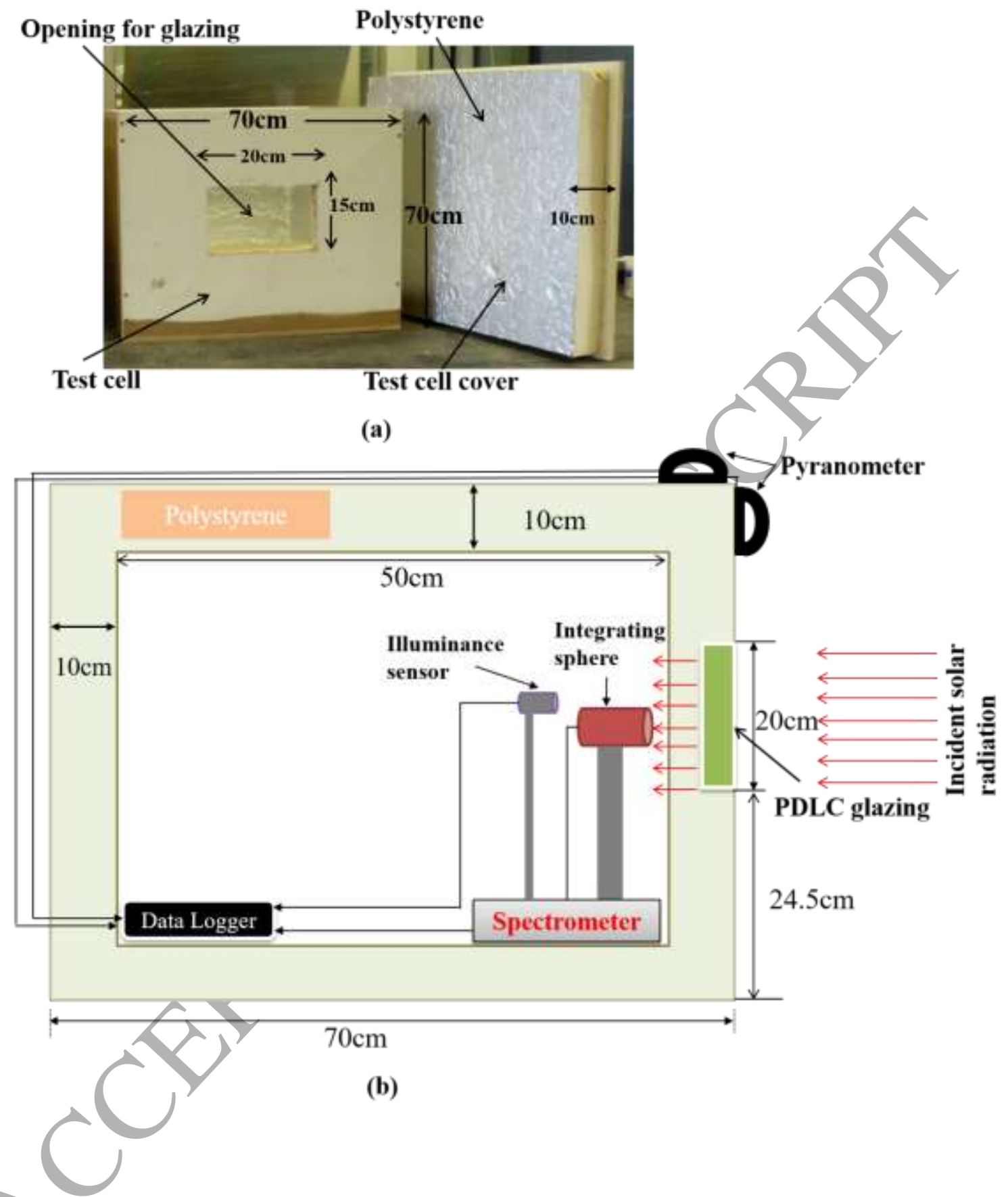

Figure 5: (a) Photograph of test cell, (b) schematic details of experimental set up for optical properties measurement of PDLC glazing using test cell, pyranomter, illuminance sensor and spectrometer.

Figures 6 shows correlation between PDLC glazing transmission with incident angle in Dublin, Ireland, for PDLC glazing in "transparent" and "opaque" states. In Dublin for vertical plane south facing glazing, incident angle varied from $53^{0}$ to $13^{0}$ on $1^{\text {st }}$ of January from 7 am to $12 \mathrm{pm}$. In the month of July, this incident angle varied from $82^{\circ}$ to $59^{\circ}$ from 7 am to $12 \mathrm{pm}$. Lower elevation angle offers higher transmission during wintertime. 


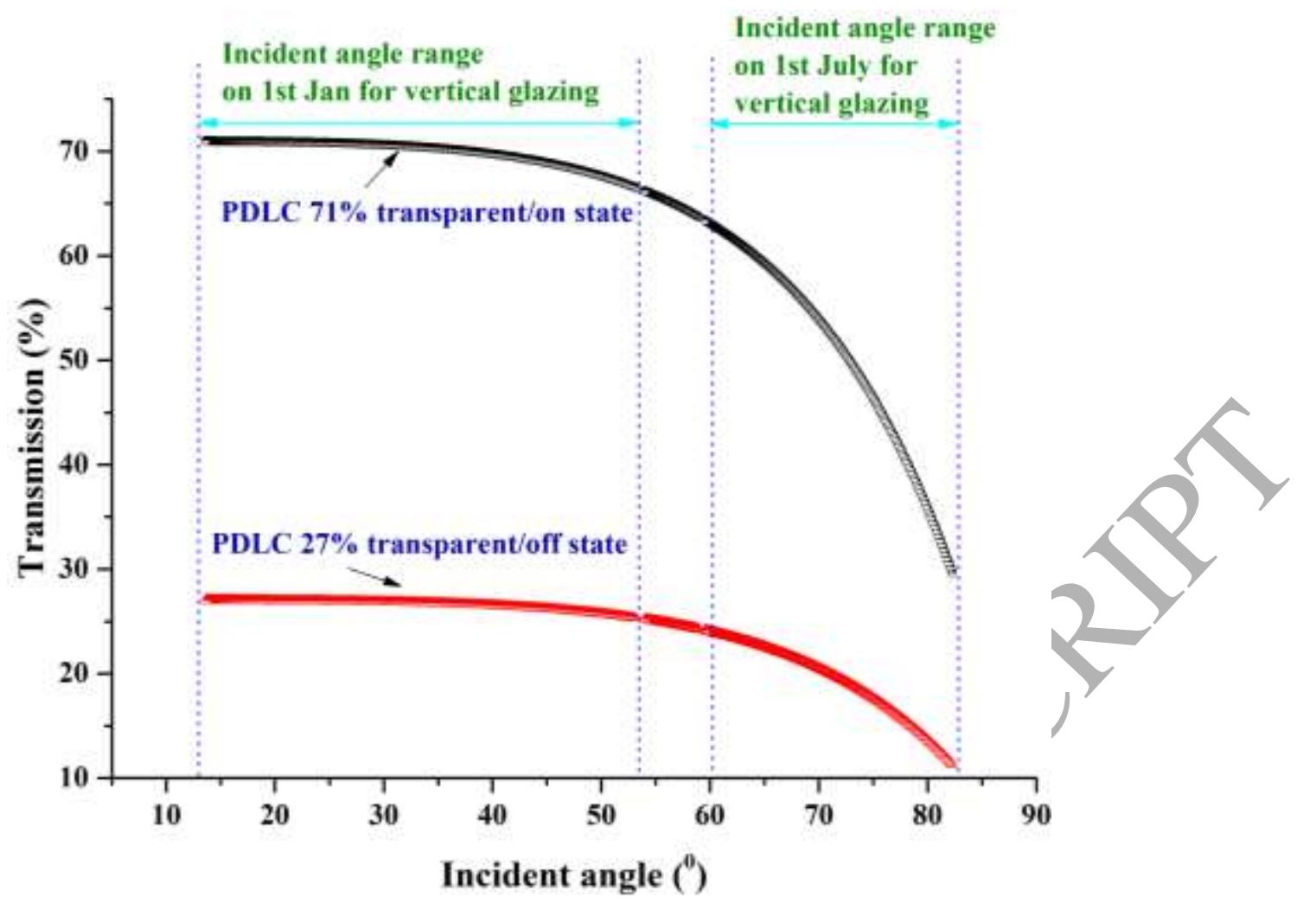

Figure 6: Variation of PDLC glazing $71 \%$ and $27 \%$ transmission for different incident angle.

Correlation between calculated clearness index and measured PDLC glazing transmission has been represented in Figure 7. Correlation between calculated clearness index and calculated transmitted solar energy (TSE) through PDLC glazing in its transparent and translucent states has been presented in Figure 8. Figure 9 shows the correlation between clearness index and PDLC glazing SHGC in transparent and translucent states. 


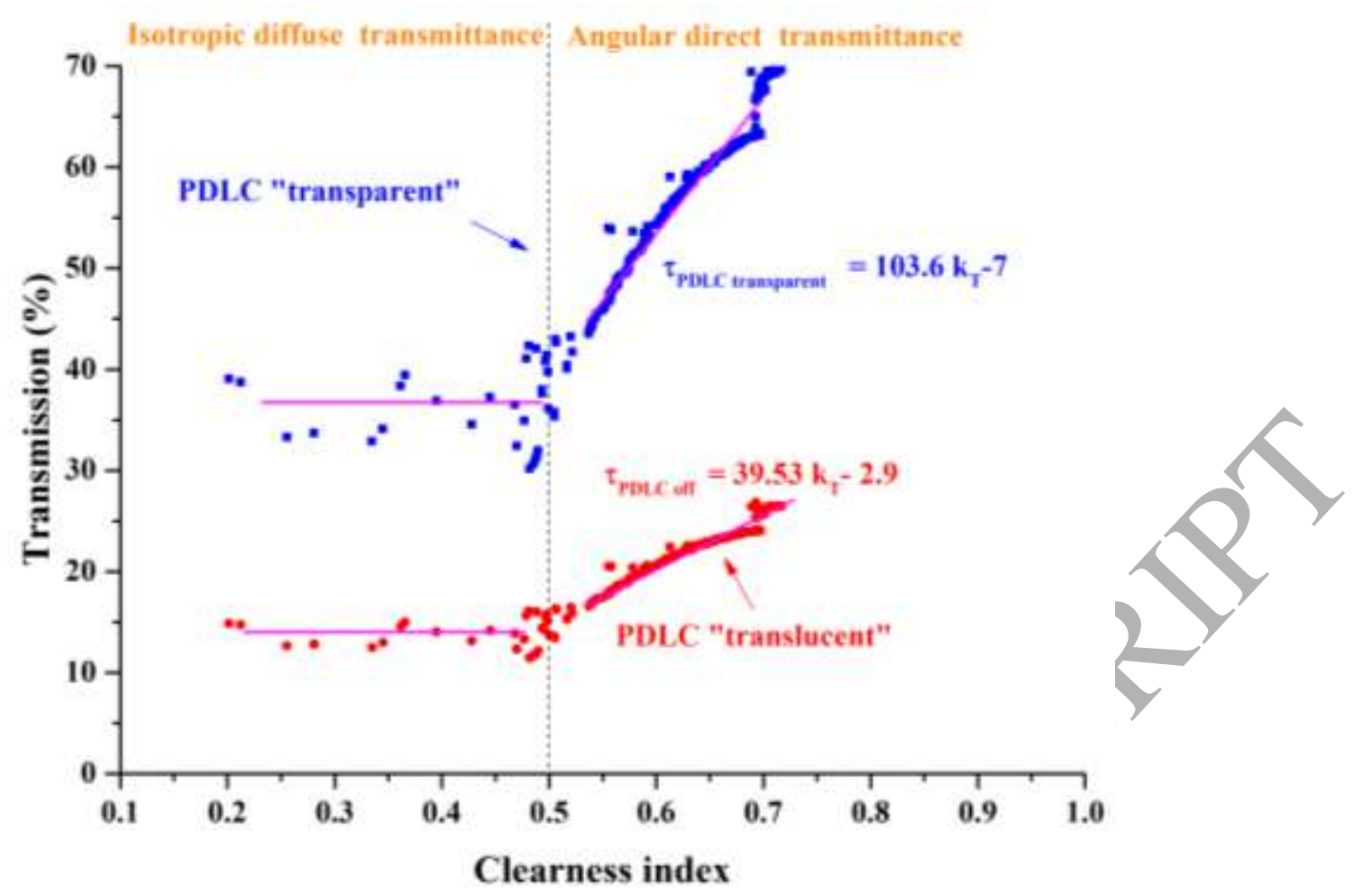

Figure 7: Change of PDLC glazing $71 \%$ and $27 \%$ transmissions due to clearness index.

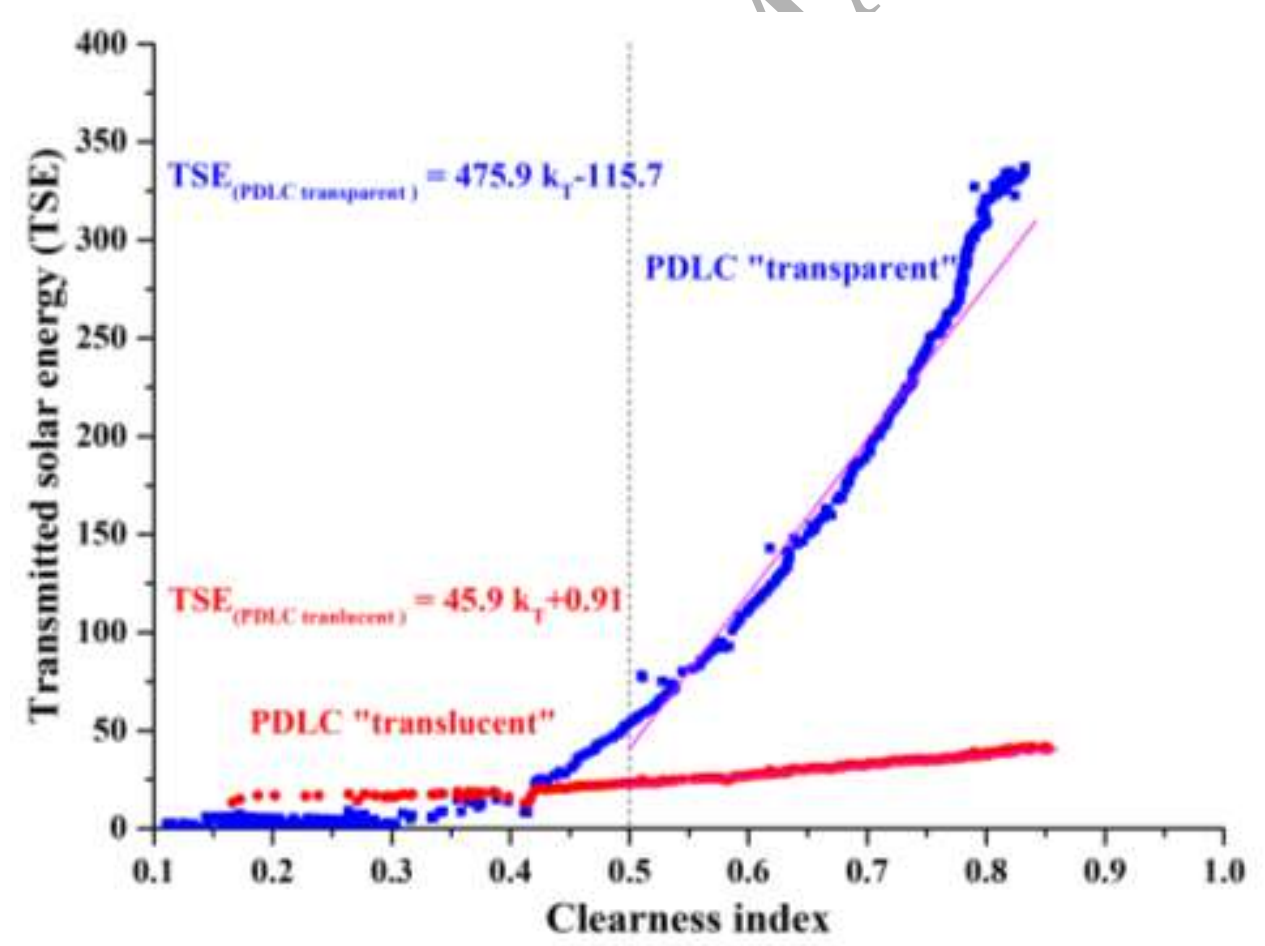

Figure 8: Dependency of transmitted solar energy (TSE) through PDLC glazing "transparent" and "translucent" states with clearness index. 


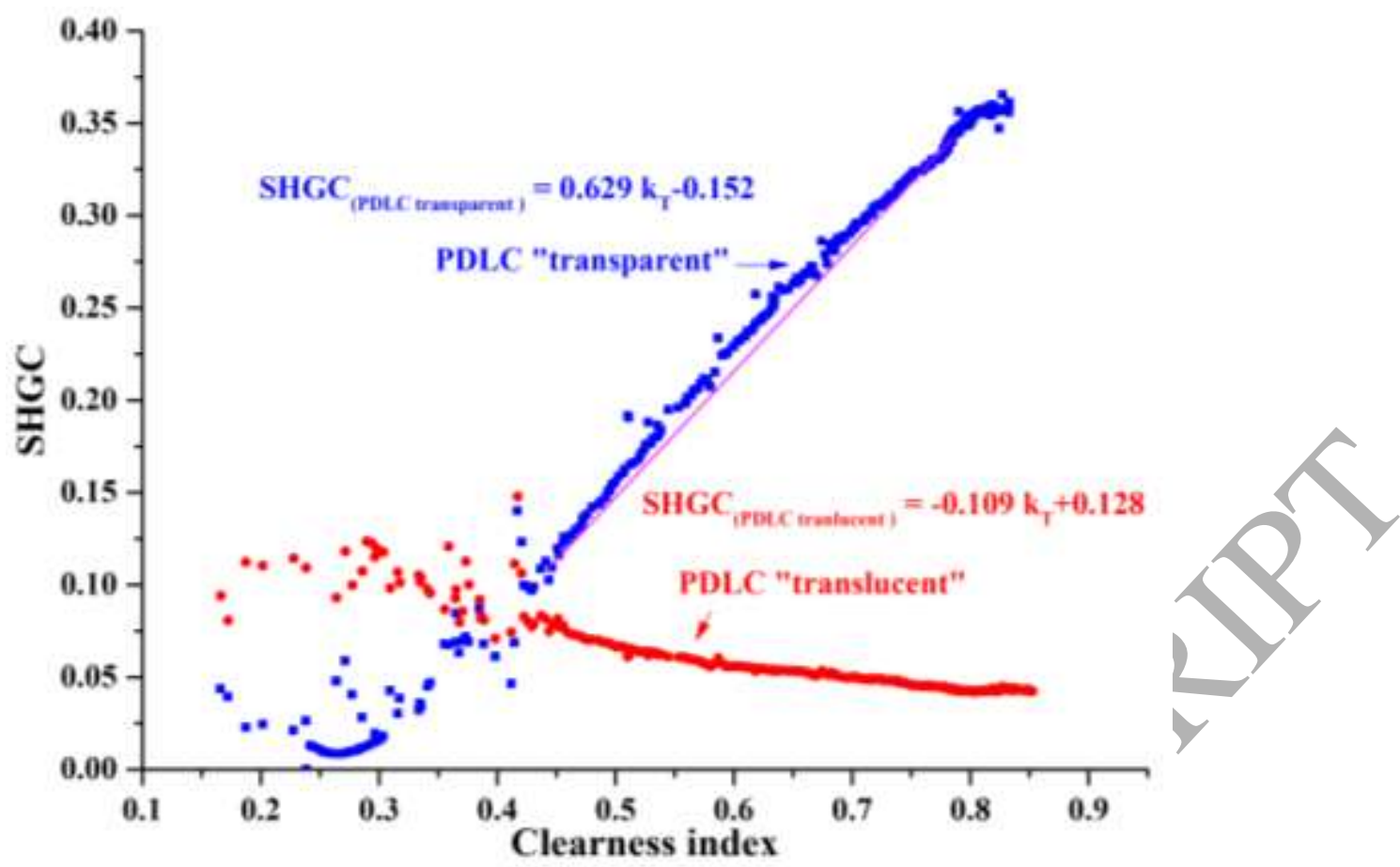

Figure 9: Dependency of SHGC of PDLC glazing "transparent" and "translucent" states with clearness index.

In figure 7 , below clearness index of 0.5 , isotropic diffuse transmission was dominant. Above 0.5 clearness index, direct solar radiation was dominant and glazing transmittance was linearly correlated with clearness index. In western European location, it is possible to use only one single transmittance value for vertical plane glazing which is associated with isotropic diffuse solar component. This single value will reduce large computational time and/or resources for building design studies. In Dublin, for below 0.5 clearness index, south facing vertical plane PDLC glazing transmission of $38 \%$ was found which could be used for building performance using PDLC glazing over the year with negligible error. For different azimuthal direction a threshold clearness index is attainable below that one single glazing transmittance can be used with less than $1 \%$ error, which is listed in Table 1.

Table 1: Yearly usable single transmittance value of PDLC transparent and translucent state for different azimuthal and monthly clearness index due to isotropic diffuse solar radiation component.

\begin{tabular}{|c|c|c|c|c|}
\hline \multirow[b]{2}{*}{ Inclination } & \multirow[b]{2}{*}{$\begin{array}{l}\text { Azimuthal } \\
\text { orientation }\end{array}$} & \multicolumn{2}{|l|}{$\begin{array}{l}\text { Single diffuse component } \\
\text { dominant }\end{array}$} & \multirow{2}{*}{$\begin{array}{l}\text { Up to a } \\
\text { clearness } \\
\text { index } \\
\text { Mean } \\
\text { monthly } \\
\text { clearness } \\
\text { index }\end{array}$} \\
\hline & & $\begin{array}{l}\text { PDLC "transparent" }(71 \% \\
\text { maximum transparent) } \\
\text { transmittance }\end{array}$ & $\begin{array}{l}\text { PDLC "translucent" (27\% } \\
\text { maximum transparent) } \\
\text { transmittance }\end{array}$ & \\
\hline \multirow{6}{*}{$\begin{array}{l}\text { Vertical } \\
\text { Plane } \\
\text { PDLC } \\
\text { glazing }\end{array}$} & North & 38 & 25 & 0.7 \\
\hline & South & 38 & 25 & 0.5 \\
\hline & East & 38 & 25 & 0.6 \\
\hline & West & 38 & 25 & 0.6 \\
\hline & North east & 38 & 25 & 0.6 \\
\hline & $\begin{array}{l}\text { North } \\
\text { west }\end{array}$ & 38 & 25 & 0.6 \\
\hline
\end{tabular}


Glazing transmittance has direct influence on transmitted solar energy and SHGC both as shown in equation 7 and 9. Thus, below 0.5 clearness index, vertical plane south facing PDLC glazing offers single yearly useable transmitted solar energy of $70 \mathrm{~W} / \mathrm{m}^{2}$ and $20 \mathrm{~W} / \mathrm{m}^{2}$, SHGC of 0.17 and 0.05 for transparent and translucent states respectively. These values can be used for building energy calculation with less than $1 \%$ error. Vertical plane PDLC glazing single transmitted solar energy and SHGC for different azimuthal direction and threshold clearness index for that particular azimuthal direction are listed in Table 2.

Table 2: Yearly usable single SHGC and TSE value of PDLC transparent and translucent state for different azimuthal and monthly clearness index due to isotropic diffuse solar radiation component.

\begin{tabular}{|c|c|c|c|c|c|c|}
\hline \multirow[b]{2}{*}{ Inclination } & \multirow[b]{2}{*}{$\begin{array}{l}\text { Azimuthal } \\
\text { direction }\end{array}$} & \multicolumn{3}{|c|}{$\begin{array}{l}\text { Single diffuse component } \\
\text { dominant }\end{array}$} & \multirow[b]{2}{*}{$\begin{array}{l}\text { PDLC } \\
\text { OFF } \\
\text { TSE } \\
\left(\mathrm{W} / \mathrm{m}^{2}\right.\end{array}$} & \multirow{2}{*}{$\begin{array}{l}\text { Up to a } \\
\text { clearness } \\
\text { index } \\
\text { Mean } \\
\text { monthly } \\
\text { clearness } \\
\text { index }\end{array}$} \\
\hline & & $\begin{array}{l}\text { PDLC } \\
\text { "transparent" } \\
\text { /ON } \\
\text { SHGC }\end{array}$ & $\begin{array}{l}\text { PDLC } \\
\text { "translucent" } \\
\text { /OFF } \\
\text { SHGC }\end{array}$ & $\begin{array}{l}\text { PDLC } \\
\text { ON } \\
\text { TSE } \\
\left(\mathrm{W} / \mathrm{m}^{2}\right)\end{array}$ & & \\
\hline \multirow{6}{*}{$\begin{array}{l}\text { Vertical } \\
\text { plane } \\
\text { PDLC } \\
\text { glazing }\end{array}$} & North & 0.17 & 0.05 & 70 & 20 & 0.7 \\
\hline & South & 0.17 & 0.05 & 70 & 20 & 0.5 \\
\hline & East & 0.17 & 0.05 & 70 & 20 & 0.6 \\
\hline & West & 0.17 & 0.05 & 70 & 20 & 0.6 \\
\hline & North east & 0.17 & 0.05 & 70 & 20 & 0.6 \\
\hline & North west & 0.17 & 0.05 & 70 & 20 & 0.6 \\
\hline
\end{tabular}

\section{Conclusions}

Clearness index is an influential parameter for solar energy application but requires only one measured solar radiation intensity to evaluate. Correlation between clearness index and glazing transmittance, transmitted solar energy (TSE) and solar heat gain coefficients (SHGC) has been evaluated for PDLC glazing in its two switched states. Below a clearness index of 0.5 , the majority of transmission is of the diffuse solar radiation. Above a clearness index of 0.5 , the glazing transmission is dominated by direct component of solar radiation. However, using a single value of transmission, SHGC, and TSE is possible for PDLC glazing transmission calculation for clearness indices below 0.5. In Dublin, a south facing vertical plane PDLC glazing below 0.5 clearness index offer $38 \%$ glazing transmittance, $70 \mathrm{~W} / \mathrm{m}^{2}$ TSE and 0.17 SGHC for transparent state and $28 \%$ glazing transmittance, $20 \mathrm{~W} / \mathrm{m}^{2}$ TSE and $0.05 \mathrm{SGHC}$ for translucent states. These can be used for calculation at all terms of year with less than $1 \%$ calculation error. 


\section{Acknowledgement}

This research did not receive any specific grant from funding agencies in the public, commercial, or not-for-profit sectors. The authors acknowledge Dublin Energy lab at Dublin Institute of Technology and Solar lab at University of Exeter for use of equipment and facilities.

\section{Reference}

[1] S.D. Rezaei, S. Shannigrahi, S. Ramakrishna, A review of conventional, advanced, and smart glazing technologies and materials for improving indoor environment, Sol. Energy Mater. Sol. Cells. 159 (2017) 26-51. doi:10.1016/j.solmat.2016.08.026.

[2] G. Gorgolis, D. Karamanis, Solar energy materials for glazing technologies, Sol. Energy Mater. Sol. Cells. 144 (2016) 559-578. doi:10.1016/j.solmat.2015.09.040.

[3] M. Sudan, G.N. Tiwari, I.M. Al-Helal, Dynamic analysis of daylight metrics and energy saving for rooftop window integrated flat roof structure of building, Sol. Energy. 122 (2015) 834846. doi:10.1016/j.solener.2015.10.012.

[4] B.P. Jelle, A. Hynd, A. Gustavsen, D. Arasteh, H. Goudey, R. Hart, Fenestration of today and tomorrow: A state-of-the-art review and future research opportunities, Sol. Energy Mater. Sol. Cells. 96 (2012) 1-28. doi:10.1016/j.solmat.2011.08.010.

[5] R. Baetens, B.P. Jelle, A. Gustavsen, Properties, requirements and possibilities of smart windows for dynamic daylight and solar energy control in buildings: A state-of-the-art review, Sol. Energy Mater. Sol. Cells. 94 (2010) 87-105. doi:10.1016/j.solmat.2009.08.021.

[6] A. Ghosh, B. Norton, T.K. Mallick, Solar Energy Materials and Solar Cells Daylight characteristics of a polymer dispersed liquid crystal switchable glazing, Sol. Energy Mater. Sol. Cells. 174 (2018) 572-576. doi:10.1016/j.solmat.2017.09.047.

[7] A. Ghosh, B. Norton, A. Duffy, Daylighting performance and glare calculation of a suspended particle device switchable glazing, Sol. Energy. 132 (2016) 114-128. doi:http://dx.doi.org/10.1016/j.solener.2016.02.051.

[8] A. Piccolo, A. Pennisi, F. Simone, Daylighting performance of an electrochromic window in a small scale test-cell, Sol. Energy. 83 (2009) 832-844. doi:10.1016/j.solener.2008.11.013.

[9] A. Piccolo, F. Simone, Effect of switchable glazing on discomfort glare from windows, Build. Environ. 44 (2009) 1171-1180. doi:10.1016/j.buildenv.2008.08.013.

[10] A. Ghosh, B. Norton, Interior colour rendering of daylight transmitted through a suspended particle device switchable glazing, Sol. Energy Mater. Sol. Cells. 163 (2017) 218-223. doi:10.1016/j.solmat.2017.01.041.

[11] H.K. Kwon, K.T. Lee, K. Hur, S.H. Moon, M.M. Quasim, T.D. Wilkinson, J.Y. Han, H. Ko, I.K. Han, B. Park, B.K. Min, B.K. Ju, S.M. Morris, R.H. Friend, D.H. Ko, Optically switchable smart windows with integrated photovoltaic devices, Adv. Energy Mater. 5 (2015) 1-6. doi:10.1002/aenm.201401347.

[12] A. Ghosh, B. Norton, A. Duffy, First outdoor characterisation of a PV powered suspended particle device switchable glazing, Sol. Energy Mater. Sol. Cells. 157 (2016) 1-9. doi:10.1016/j.solmat.2016.09.049.

[13] A.L. Dyer, R.H. Bulloch, Y. Zhou, B. Kippelen, J.R. Reynolds, F. Zhang, A vertically integrated 
solar-powered electrochromic window for energy efficient buildings, Adv. Mater. 26 (2014) 4895-4900. doi:10.1002/adma.201401400.

[14] A. Cannavale, G.E. Eperon, P. Cossari, A. Abate, H.J. Snaith, G. Gigli, Perovskite photovoltachromic cells for building integration, Energy Environ. Sci. 8 (2015) 1578-1584. doi:10.1039/C5EE00896D.

[15] J. Wang, L. Zhang, L. Yu, Z. Jiao, H. Xie, X.W. (David) Lou, X. Wei Sun, A bi-functional device for self-powered electrochromic window and self-rechargeable transparent battery applications, Nat. Commun. 5 (2014) 4921. doi:10.1038/ncomms5921.

[16] Y. Fang, T.J. Hyde, F. Arya, N. Hewitt, P.C. Eames, B. Norton, S. Miller, Indium alloy-sealed vacuum glazing development and context, Renew. Sustain. Energy Rev. 37 (2014) 480-501. doi:10.1016/j.rser.2014.05.029.

[17] A. Ghosh, B. Norton, A. Duffy, Effect of sky clearness index on transmission of evacuated (vacuum) glazing, Renew. Energy. 105 (2017) 160-166. doi:10.1016/j.renene.2016.12.056.

[18] A. Ghosh, B. Norton, A. Duffy, Measured thermal \& daylight performance of an evacuated glazing using an outdoor test cell, Appl. Energy. 177 (2016) 196-203. doi:10.1016/j.apenergy.2016.05.118.

[19] A. Ghosh, B. Norton, A. Duffy, Effect of atmospheric transmittance on performance of adaptive SPD-vacuum switchable glazing, Sol. Energy Mater. Sol. Cells. 161 (2017) 424-431. doi:10.1016/j.solmat.2016.12.022.

[20] A. Ghosh, B. Norton, A. Duffy, Measured thermal performance of a combined suspended particle switchable device evacuated glazing, Appl. Energy. 169 (2016) 469-480. doi:10.1016/j.apenergy.2016.02.031.

[21] Y. Fang, P.C. Eames, Thermal performance of an electrochromic vacuum glazing, Energy Convers. Manag. 47 (2006) 3602-3610. doi:10.1016/j.enconman.2006.03.016.

[22] Y. Fang, P.C. Eames, The effect of glass coating emittance and frame rebate on heat transfer through vacuum and electrochromic vacuum glazed windows, Sol. Energy Mater. Sol. Cells. 90 (2006) 2683-2695. doi:10.1016/j.solmat.2006.04.006.

[23] Y. Fang, P.C. Eames, B. Norton, T. Hyde, Y. Huang, N. Hewitt, The thermal performance of an electrochromic vacuum glazing with selected low-emittance coatings, Thin Solid Films. 516 (2008) 1074-1081. doi:10.1016/j.tsf.2007.07.210.

[24] Y. Fang, T. Hyde, N. Hewitt, P.C. Eames, B. Norton, Thermal performance analysis of an electrochromic vacuum glazing with low emittance coatings, Sol. Energy. 84 (2010) 516-525. doi:10.1016/j.solener.2009.02.007.

[25] S. Papaefthimiou, G. Leftheriotis, P. Yianoulis, T.J. Hyde, P.C. Eames, Y. Fang, P.Y. Pennarun, P. Jannasch, Development of electrochromic evacuated advanced glazing, Energy Build. 38 (2006) 1455-1467. doi:10.1016/j.enbuild.2006.03.029.

[26] N. DeForest, A. Shehabi, G. Garcia, J. Greenblatt, E. Masanet, E.S. Lee, S. Selkowitz, D.J. Milliron, Regional performance targets for transparent near-infrared switching electrochromic window glazings, Build. Environ. 61 (2013) 160-168. doi:10.1016/j.buildenv.2012.12.004.

[27] A. Ghosh, B. Norton, A. Duffy, Measured overall heat transfer coefficient of a suspended 
particle device switchable glazing, Appl. Energy. 159 (2015) 362-369. doi:10.1016/j.apenergy.2015.09.019.

[28] C.G. Granqvist, Electrochromic tungsten oxide films: Review of progress 1993-1998, Sol. Energy Mater. Sol. Cells. 60 (2000) 201-262. doi:10.1016/S0927-0248(99)00088-4.

[29] C.G. Granqvist, Oxide electrochromics: An introduction to devices and materials, Sol. Energy Mater. Sol. Cells. 99 (2012) 1-13. doi:10.1016/j.solmat.2011.08.021.

[30] C.G. Granqvist, Electrochromics for smart windows : Oxide-based thin fi Ims and devices, Thin Solid Films. 564 (2014) 1-38. doi:10.1016/j.tsf.2014.02.002.

[31] C.G. Granqvist, Recent progress in thermochromics and electrochromics: A brief survey, Thin Solid Films. 614 (2015) 90-96. doi:10.1016/j.tsf.2016.02.029.

[32] C.M. Lampert, A. Agrawal, C. Baertlien, J. Nagai, Durability evaluation of electrochromic devices - an industry perspective, Sol. Energy Mater. Sol. Cells. 56 (1999) 449-463. doi:10.1016/S0927-0248(98)00185-8.

[33] E.S. Lee, D.L. DiBartolomeo, Application issues for large-area electrochromic windows in commercial buildings, Sol. Energy Mater. Sol. Cells. 71 (2002) 465-491. doi:10.1016/S09270248(01)00101-5.

[34] R. Vergaz, J.M. Sánchez-Pena, D. Barrios, C. Vázquez, R. Contreras-Lallana, Modelling and electro-optical testing of suspended particle devices, Sol. Energy Mater. Sol. Cells. 92 (2008) 1483-1487. doi:10.1016/j.solmat.2008.06.018.

[35] D. Barrios, R. Vergaz, J.M. Sanchez-Pena, C.G. Granqvist, G.A. Niklasson, Toward a quantitative model for suspended particle devices: Optical scattering and absorption coefficients, Sol. Energy Mater. Sol. Cells. 111 (2013) 115-122.

doi:10.1016/j.solmat.2012.12.012.

[36] D. Barrios, R. Vergaz, J.M. Sánchez-Pena, B. García-Cámara, C.G. Granqvist, G.A. Niklasson, Simulation of the thickness dependence of the optical properties of suspended particle devices, Sol. Energy Mater. Sol. Cells. 143 (2015) 613-622. doi:10.1016/j.solmat.2015.05.044.

[37] A. Ghosh, B. Norton, A. Duffy, Behaviour of a SPD switchable glazing in an outdoor test cell with heat removal under varying weather conditions, Appl. Energy. 180 (2016) 695-706. doi:10.1016/j.apenergy.2016.08.029.

[38] A. Ghosh, B. Norton, Durability of switching behaviour after outdoor exposure for a suspended particle device switchable glazing, Sol. Energy Mater. Sol. Cells. 163 (2017) 178184. doi:10.1016/j.solmat.2017.01.036.

[39] A. Ghosh, T.K. Mallick, Evaluation of colour properties due to switching behaviour of a PDLC glazing for adaptive building integration, Renew. Energy. 120 (2018) 126-133. doi:10.1016/j.renene.2017.12.094.

[40] G. Macrelli, Optical characterization of commercial large area liquid crystal devices, Sol. Energy Mater. Sol. Cells. 39 (1995) 123-131. doi:10.1016/0927-0248(95)00044-5.

[41] D.J. Gardiner, S.M. Morris, H.J. Coles, High-efficiency multistable switchable glazing using smectic A liquid crystals, Sol. Energy Mater. Sol. Cells. 93 (2009) 301-306. doi:10.1016/j.solmat.2008.10.023. 
[42] G.P. Montgomery, J.L. West, W. Tamura-Lis, Light scattering from polymer-dispersed liquid crystal films: Droplet size effects, J. Appl. Phys. 69 (1991) 1605-1612. doi:10.1063/1.347256.

[43] D. Cupelli, F.P. Nicoletta, S. Manfredi, M. Vivacqua, P. Formoso, G. De Filpo, G. Chidichimo, Self-adjusting smart windows based on polymer-dispersed liquid crystals, Sol. Energy Mater. Sol. Cells. 93 (2009) 2008-2012. doi:10.1016/j.solmat.2009.08.002.

[44] D. Cupelli, F.P. Nicoletta, S. Manfredi, G. De Filpo, G. Chidichimo, Electrically switchable chromogenic materials for external glazing, Sol. Energy Mater. Sol. Cells. 93 (2009) 329-333. doi:10.1016/j.solmat.2008.11.010.

[45] M. Rubin, Optical properties of soda lime silica glasses, Sol. Energy Mater. 12 (1985) 275-288. doi:10.1016/0165-1633(85)90052-8.

[46] J. Karlsson, M. Rubin, A. Roos, Evaluation of predictive models for the angle-dependent total solar energy transmittance of glazing materials, Sol. Energy. 71 (2001) 23-32.

doi:10.1016/S0038-092X(01)00024-X.

[47] J. Karlsson, A. Roos, Modelling the angular behaviour of the total solar energy transmittance of windows, Sol. Energy. 69 (2000) 321-329. doi:10.1016/S0038-092x(00)00083-9.

[48] M. Rubin, R. Powles, K. Von Rottkay, Models for the angle-dependent optical properties of coated glazing materials, Sol. Energy. 66 (1999) 267-276. doi:10.1016/S0038-092X(99)000298.

[49] M.C. Singh, S.N. Garg, An empirical model for angle-dependent g-values of glazings, Energy Build. 42 (2010) 375-379. doi:10.1016/j.enbuild.2009.10.004.

[50] R. Perez, R. Stewart, C. Arbogast, R. Seals, J. Scott, An anisotropic hourly diffuse radiation model for sloping surfaces: Description, performance validation, site dependency evaluation, Sol. Energy. 36 (1986) 481-497. doi:10.1016/0038-092X(86)90013-7.

[51] R. Perez, R. Seals, J. Michalsky, All-weather model for sky luminance distribution-Preliminary configuration and validation, Sol. Energy. 50 (1993) 235-245. doi:10.1016/0038092X(93)90017-I.

[52] R. Perez, P. Ineichen, R. Seals, A. Zelenka, Making full use of the clearness index for parameterizing hourly insolation conditions, Sol. Energy. 45 (1990) 111-114. doi:10.1016/0038-092X(90)90036-C.

[53] P.A. Waide, B. Norton, Variation of insolation transmission with glazing plane position and sky conditions, Trans. Am. Soc. Mech. Eng. J. Sol. Energy Eng. 125 (2003) 182-189. doi:10.1115/1.1563630.

[54] A. Ghosh, B. Norton, A. Duffy, Effect of sky conditions on light transmission through a suspended particle device switchable glazing, Sol. Energy Mater. Sol. Cells. 160 (2017) 134140. doi:10.1016/j.solmat.2016.09.049.

[55] M.J. Brandemuehl, W.A. Beckman, Transmission of diffuse radiation through CPC and flat plate collector glazings, Sol. Energy. 24 (1980) 511-513. doi:10.1016/0038-092X(80)90320-5.

[56] T.E. Kuhn, Calorimetric determination of the solar heat gain coefficient $\mathrm{g}$ with steady-state laboratory measurements, Energy Build. 84 (2014) 388-402. doi:10.1016/j.enbuild.2014.08.021. 
[57] A. Ghosh, T.K. Mallick, Evaluation of optical properties and protection factors of a PDLC switchable glazing for low energy building integration, Sol. Energy Mater. Sol. Cells. (2017) 01. doi:10.1016/j.solmat.2017.10.026.

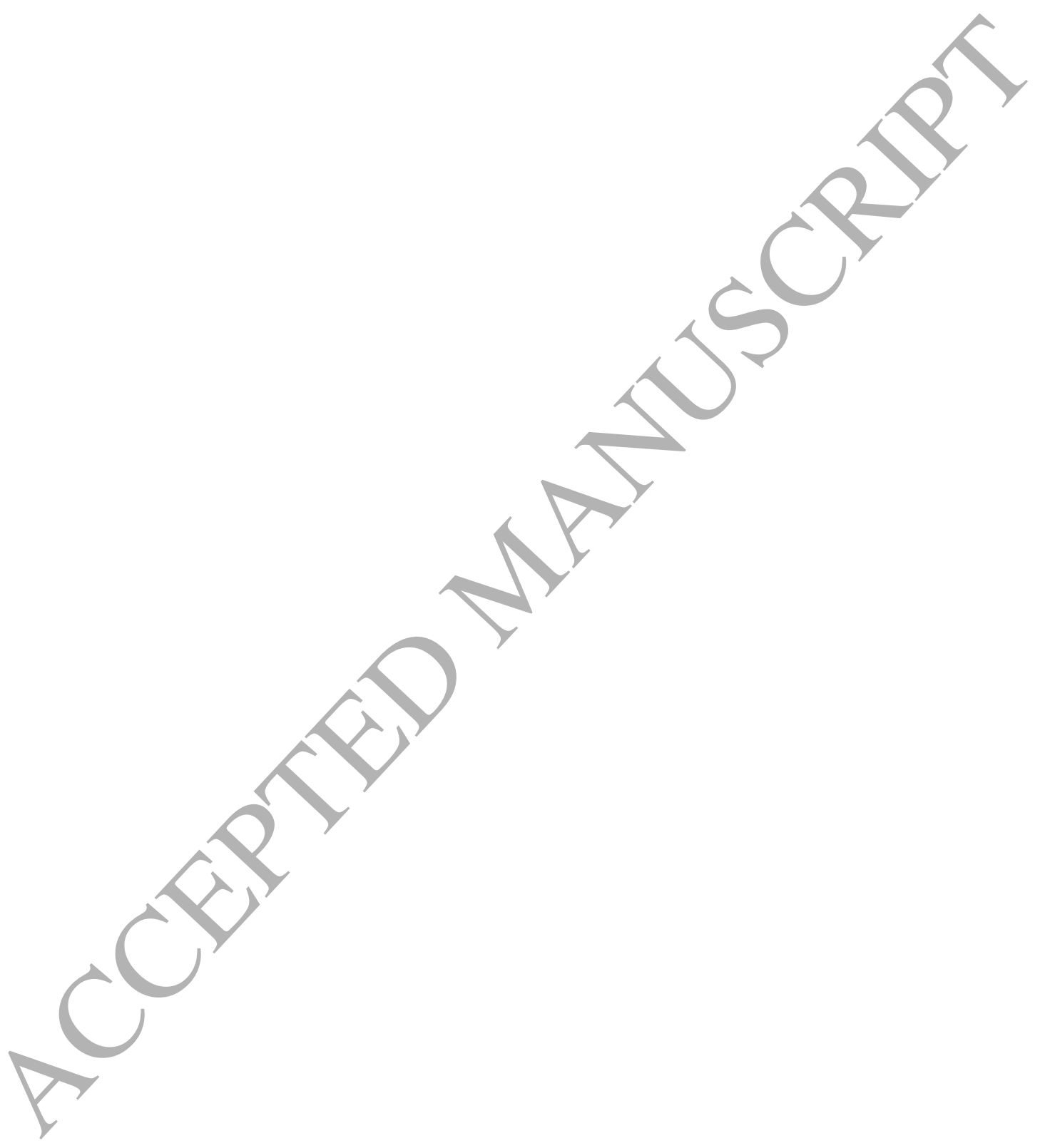

